\title{
Effect of mechanical loading on insulin-like growth factor-I gene expression in rat tibia
}

\author{
Christianne M A Reijnders' ${ }^{1}$, Nathalie Bravenboer ${ }^{1,2}$, Annechien M Tromp ${ }^{1}$, Marinus A Blankenstein ${ }^{2}$ \\ and Paul Lips ${ }^{1}$
}

Departments of ${ }^{1}$ Endocrinology and ${ }^{2}$ Clinical Chemistry, VU University Medical Center, De Boelelaan 1117, brug 124, PO Box 7057, 1081 HV Amsterdam, The Netherlands

(Requests for offprints should be addressed to N Bravenboer; Email: n.bravenboer@vumc.nl)

\begin{abstract}
Mechanical loading plays an essential role in maintaining skeletal integrity. Mechanical stimulation leads to increased bone formation. However, the cellular and molecular mechanisms that are involved in the translation of mechanical stimuli into bone formation, are not completely understood. Growth factors and osteocytes, which act as mechanosensors, play a key role during the bone formation after mechanical stimulation. The aim of this study was to characterize the role of IGF-I in the translation of mechanical stimuli into bone formation locally in rat tibiae. Fifteen female Wistar rats were randomly assigned to three groups $(n=5)$ : load, sham-loaded, and control. The fourpoint bending model of Forwood and Turner was used to induce a single period of mechanical loading on the tibia shaft. The effects of mechanical loading on IGF-I mRNA expression were determined with non-radioactive in situ hybridization on decalcified tibiae sections, $6 \mathrm{~h}$ after the loading session. Endogenous IGF-I mRNA was expressed in trabecular and cortical osteoblasts, some trabecular and sub-endocortical osteocytes, intracortical endothelial cells of blood vessels, and periosteum. Megakaryocytes,
\end{abstract}

macrophages, and myeloid cells also expressed IGF-I mRNA. In the growth plate, IGF-I mRNA was located in proliferative and hypertrophic chondrocytes. Mechanical loading did not affect the IGF-I mRNA expression in osteoblasts, bone marrow cells, and chondrocytes, but the osteocytes at the endosteal side of the shaft showed a twofold increase of IGF-I mRNA expression. The proportion of IGF-I mRNA positive osteocytes in loaded tibiae was $29 \cdot 3 \pm 12 \cdot 9 \%$ (mean \pm s.D.; $n=5)$, whereas sham-loaded and contra-lateral control tibiae exhibited $16 \cdot 7 \pm 4 \cdot 4 \% \quad(n=5)$ and $14 \cdot 7 \pm 4 \cdot 2 \%(n=10)$ respectively $(P<0 \cdot 05)$. Lamellar bone formation after a single mechanical loading session was observed at the endosteal side of the shaft. In conclusion, a single loading session results in a twofold up-regulation of IGF-I mRNA synthesis in osteocytes which are present in multiple layers extending into the cortical bone of mechanically stimulated tibia shaft $6 \mathrm{~h}$ after loading. This supports the hypothesis that IGF-I, which is located in osteocytes, is involved in the translation of mechanical stimuli into bone formation.

Journal of Endocrinology (2007) 192, 131-140

\section{Introduction}

Mechanical loading plays an essential role in maintaining the skeletal integrity in both humans and animals (Forwood \& Parker 1991, Turner et al. 1991, 1994, Smith \& Rutherford 1993, Yeh et al. 1993, Hamdy et al. 1994, Torrance et al. 1994, van der Wiel et al. 1995, Forwood et al. 1998). Bone modifies its structure throughout life in order to serve as a structural support for the body. According to the mechanostat theory, decreased physical activity results in decreased bone formation and increased bone resorption, whereas increased physical activity has the opposite effect (Yeh et al. 1993). It has been suggested that osteocytes function as mechanosensors via canalicular processes and communicating gap junctions in the early stage of bone remodeling (Cowin et al. 1991, Nomura \& Takano-Yamamoto 2000).
Several in vivo studies have shown that many biochemical signal molecules are involved in the translation of mechanical stimuli into bone formation including glucose-6-phosphate dehydrogenase (G6PD) (Skerry et al. 1989, Lanyon 1992), c-fos (Raab-Cullen et al. 1994, Lean et al. 1996), cAMP (Davidovitch et al. 1984), cyclooxygenase (COX-2) (Forwood 1996), nitric oxide (NO) and prostanoid (Pitsillides et al. 1995), insulin-like growth factors (IGFs) (Raab-Cullen et al. 1994, Lean et al. 1995, Bravenboer et al. 2001), transforming growth factor- $\beta$ (TGF- $\beta$ ) (Raab-Cullen et al. 1994, Bravenboer et al. 2001), protein kinase B (PKB or Akt) (Skerry \& Suva 2003), and glutamate transporter (GLAST) (Mason et al. 1997, Skerry 1999, Skerry \& Genever 2001, Skerry \& Suva 2003). These responses to in vivo mechanical loading are time- and spatially-dependent. Early strain related changes within 5 min after loading are shown in osteocytes in which the G6PD activity is increased (Skerry et al. 
1989, Lanyon 1992), whereas an increase of IGF-I mRNA expression is located on trabecular surfaces and in osteocytes of the diaphysial cortex (cortical and trabecular osteocytes) of rat caudal vertebrae within $6 \mathrm{~h}$ after a single loading session (Lean et al. 1995).

The aim of this study was to characterize the role of IGF-I mRNA in the cortical tibia shaft during the translation of mechanical stimuli into bone formation. To this end, we developed an in situ hybridization method especially for bone tissue to detect the local osteogenic response on cellular level $6 \mathrm{~h}$ after a single period of dynamic loading. To induce a single period of mechanical loading the four-point bending model of Forwood and Turner has been used (Turner et al. 1991, 1994, Forwood et al. 1998) resulting in bone formation in the rat tibia 5-8 days after stimulation (Forwood et al. 1996).

\section{Materials and Methods}

\section{Study design}

This study comprised two parts: (1) validation study of the four-point bending system to verify bone formation after a single mechanical loading session and (2) detection of changes in mRNA expression of IGF-I after a single mechanical loading session with non-radioactive in situ hybridization.

The animal experiments were in accordance with the governmental guidelines for care and use of laboratory animals and approved by the Institutional Animal Care and Use Committee (IACUC) of the VU University Medical Center Amsterdam, The Netherlands.

\section{Validation study four-point bending system}

Female Wistar rats of 12-weeks old (Harlan, Zeist, The Netherlands) were randomly assigned into two groups $(n=3$ per group): LOAD and SHAM. The right tibiae underwent 'medio-lateral' loading (LOAD) (distance between the centers of the loading pads: upper pads, $11 \mathrm{~mm}$ and lower pads, $23 \mathrm{~mm}$ ) or sham-loading (SHAM) (opposed pads were placed at the inner position: $11 \mathrm{~mm}$ ) using the four-point bending system of Forwood and Turner (Fig. 1, Turner et al. 1991, Forwood et al. 1998). Since loading will result in bending and squeezing of the tibia and sham-loading only in squeezing of the tibia, the SHAM group was used as control for the LOAD group. The left nonloaded tibiae served as contra-lateral controls (CONTROL). The four-point bending model (Forwood et al. 1996) was used to generate a single period of dynamic loading of the right tibia in rats in vivo. The rats were subjected to a single episode of loading comprising 300 cycles $(2 \mathrm{~Hz}$ ) using a peak magnitude of $60 \mathrm{~N}$, which generates a mean strain of $2664 \mu$ strain in the loaded tibia compared with a mean strain of $350 \mu$ strain in the sham-loaded tibia (Forwood et al. 1998). Tetracycline (25 mg/ $\mathrm{kg}$ body weight) was administered intraperitoneally to the rats, 5 and 12 days after the single loading session. The rats were killed 15 days after loading.

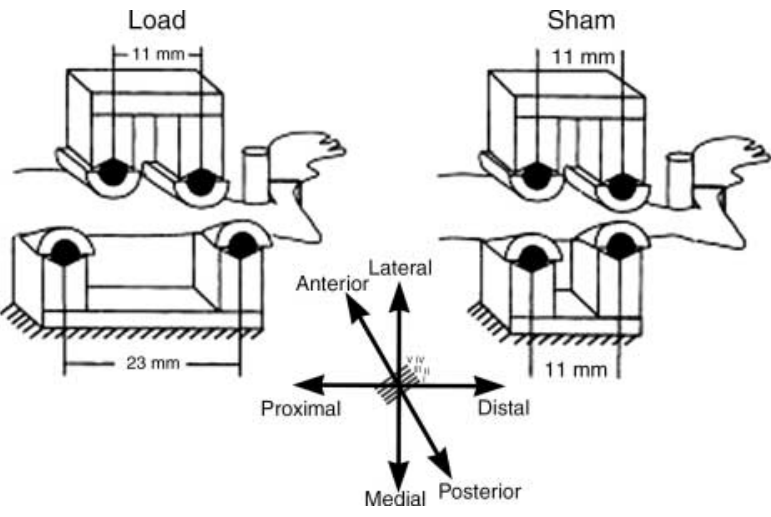

Figure 1 Four-point bending model including a schematic of sectioning. LOAD, a mediolateral bending moment is produced in the shaft of the tibia when a force is applied to the upper device. The distance between the two upper padded load points is $11 \mathrm{~mm}$ and between the lower points is $23 \mathrm{~mm}$; SHAM, the lower points are removed inward so that they directly oppose the upper points $(11 \mathrm{~mm})$. When a force is applied to the upper device, it will squeeze the shaft of the tibia and the surrounding soft tissues, like muscles, but no bending of the shaft occurs. The direction of sectioning was performed in the posterior-anterior direction. The semi-quantitative analysis comprised of 5 sections per tibia with a distance of 50 sections in between respectively shown as sections $I-V$, covering the whole tibia. Figure used with written permission of $\mathrm{Dr} \mathrm{CH}$ Turner. Reprinted from Robling AG, Burr DB \& Turner CH 2001 Skeletal loading in animals. Journal of Musculoskeletal and Neuronal Interactions 1 249-262.

The tibiae were removed, fixed in $4 \%$ phosphate buffered formaldehyde, and embedded in methyl metacrylate (mma). Three cross-sectional sections of $30 \mu \mathrm{m}$ were sawn with a sawing microtome (FMTA, Amsterdam, The Netherlands) through the region of applied loading or through the corresponding region of the contra-lateral tibia. The endosteal surfaces of all sections were used for histomorphometry measurements. Mineralizing surface (MS/BS (\% BS: bone surface)) and mineral apposition rate (MAR $(\mu \mathrm{m} /$ day)) were measured semi-automatically using Osteomeasure (OsteoMetrics Inc Decatur, GA, USA). MAR was defined as the mean distance between the fluorescent labels, divided by the labeling period. Nomenclature and calculations were according to the American Society of Bone and Mineral Research nomenclature committee. Data are expressed as mean values of the analyzed sections. Since the sample size was limited, statistical analyses were not made.

\section{In vivo mechanical loading in situ hybridization}

Fifteen female 12-week-old Wistar rats $(235 \pm 12 \mathrm{~g})$ (Harlan) were randomly assigned to three weight-matched groups $(n=$ 5/group): LOAD, SHAM, and CONTROL. The right tibiae underwent 'medio-lateral' loading (LOAD), sham-loading (SHAM), or no loading (CONTROL) using the four-point bending system of Forwood and Turner (Fig. 1, Turner et al. 1991, Forwood et al. 1998). The left tibiae served as contralateral controls. The four-point bending model (Forwood 
et al. 1996) was used to generate a single period of dynamic loading of the right tibia in rats in vivo in order to detect acute changes of IGF-I mRNA locally in bone tissue after stimulation by mechanical stress. The rats were subjected to a single episode of loading comprising 300 cycles $(2 \mathrm{~Hz})$ using a peak magnitude of $60 \mathrm{~N}$. The loading experiment was performed under general anesthesia $(2 \%$ isoflurane in $11 / \mathrm{min}$ $\mathrm{O}_{2}$ and $2 \mathrm{l} / \mathrm{min} \mathrm{N}_{2} \mathrm{O}$ ). The rats were killed exactly $6 \mathrm{~h}$ after loading. This time point was based on literature (Lean et al. 1995) which was confirmed by a time-course pilot experiment at our laboratory using real-time reverse transcriptase (RT)-PCR analysis ( $\mathrm{H} \mathrm{W}$ van Essen, personal communication). The tibiae were dissected and immediately fixed in $4 \%(\mathrm{wt} / \mathrm{vol})$ paraformaldehyde (buffered in PBS, $\mathrm{pH}$ $7 \cdot 4)$ at $4{ }^{\circ} \mathrm{C}$ for $24 \mathrm{~h}$.

\section{Tissue}

After the fixation, the tibiae were decalcified in $10 \%$ EDTA with $0.5 \%$ paraformaldehyde in PBS at $4{ }^{\circ} \mathrm{C}$ for $4 \frac{1}{2}$ weeks. Finally, the tibiae were washed in PBS and dehydrated through a series of ethanol and xylene at room temperature and embedded in paraffin.

Control brains were dissected rostrally to the cerebellum (interaural coordinate $0 \mathrm{~mm}$ ) and the hippocampus (interaural coordinate $4 \mathrm{~mm}$ ) in three coronal blocks and immediately fixed in $4 \%$ (wt/vol) paraformaldehyde (buffered in PBS, $\mathrm{pH}$ $7 \cdot 4$ ) at $4{ }^{\circ} \mathrm{C}$ for $24 \mathrm{~h}$, followed by washing in PBS, dehydration through a series of ethanol and xylene at room temperature and embedding in paraffin.

\section{Reagents}

All restriction enzymes and modifying enzymes were purchased from Roche Molecular Biochemicals, as well as digoxigeninUTP, anti-digoxigenin Fab fragments, nitro-blue-tetrazolium chloride, 5-bromo-4-chloro-3-indolyl phosphate, and blocking reagent. Nylon membranes were purchased from Qiagen. Polyvinyl alcohol was obtained from Aldrich (Milwaukee, WI, USA). Euparal mounting medium was purchased from Chroma Gesellschaft (Schmid GmbH, Köngen, The Netherlands). Silane-coated glass slides were obtained from Sigma-Aldrich (St Louis, MO, USA).

rRNA and human IGF-I cDNA was kindly provided by Dr S C van Buul-Offers (Department of Metabolic and Endocrine Diseases, University Medical Center Utrecht, Utrecht, The Netherlands).

\section{Synthesis of digoxigenin-labeled complementary RNA (cRNA) probes}

Standard in vitro transcription reactions were carried out using T7- and Sp6-RNA polymerase with digoxigenin-UTP as a substrate (Melton et al. 1984). cDNA encoding ribosomal 28S RNA and human IGF-I (259 bp, containing exon 2 and 3, 120-379 nt, gene ID X00173) (Jansen et al. 1983) were used as a template for the synthesis of antisense and sense digoxigenin-labeled RNA probe. The probe was specific for the mRNAs analyzed. The IGF-I probe was checked for cross-hybridization using in situ hybridization on spleen and growth plate cartilage (Smink et al. 2002).

\section{Non-radioactive in situ hybridization}

Serial, longitudinal, tibia sections $(5 \mu \mathrm{m})$, which were cut in posterior-anterior direction, and cross-sectional control brain sections $(5 \mu \mathrm{m})$ were mounted onto RNase-free silane-coated glass slides and dried at $56^{\circ} \mathrm{C}$ for at least 3 days. In situ hybridization was performed on every 50 th section with a total of five slides per tibia (i.e., sections I, II, III, IV, and V; Fig. 1). Sections I, II, III, IV, and V included the loading zone of the loaded and sham-loaded tibia and were taken to obtain regular sampling throughout the whole tibia. Corresponding sections of the right and the left tibia sections of one rat were mounted on the same glass slide. All sections were dewaxed, rehydrated, and rinsed in water. The sections were pretreated with $0 \cdot 2 \mathrm{M} \mathrm{HCl}$ for $15 \mathrm{~min}$ at room temperature, permeabilized in proteinase $\mathrm{K}$ $(15 \mu \mathrm{g} / \mathrm{ml})$ for $30 \mathrm{~min}$ at $37^{\circ} \mathrm{C}$, and subjected to an acetylation treatment (Wilkinson 1992). The sections were rinsed in $2 \times$ SSC ( $0.3 \mathrm{M}$ sodium chloride and $0.03 \mathrm{M}$ sodium citrate) and kept in this solution until the start of the hybridization.

Hybridization was performed in a solution containing 50\% formamide, $2 \times$ SSC, $1 \times$ Denhardt's solution, $250 \mu \mathrm{g} / \mathrm{ml}$ tRNA, $480 \mu \mathrm{g} / \mathrm{ml}$ herring sperm RNA, 10\% dextran-sulfate and the rRNA digoxigenin-labeled cRNA probe at a concentration of $250 \mathrm{pg} / \mu \mathrm{l}$ and the human IGF-I (hIGF-I) digoxigenin-labeled cRNA probe at a concentration of $1500 \mathrm{pg} / \mu \mathrm{l}$. Sections were hybridized overnight at $53^{\circ} \mathrm{C}$. After hybridization, sections were washed with $50 \%$ formamide in $2 \times \mathrm{SSC}$ at the hybridization temperature for $30 \mathrm{~min}$ and treated with RNase A (1 unit/ml) for $30 \mathrm{~min}$ at $37^{\circ} \mathrm{C}$. Subsequently, sections were rinsed in $2 \times \mathrm{SSC}$, treated with $1 \%$ blocking reagent for $30 \mathrm{~min}$, and incubated with sheep antidigoxigenin $\mathrm{Fab}$ fragments conjugated with alkaline phosphatase $(1: 1500) \mathrm{O} / \mathrm{N}$ at $4{ }^{\circ} \mathrm{C}$.

Chromogenesis was performed in the dark with $0.38 \mathrm{mg} / \mathrm{ml}$ nitro-blue-tetrazolium chloride (NBT) and $0 \cdot 19 \mathrm{mg} / \mathrm{ml}$ 5-bromo-4-chloro-3-indolyl phosphate (BCIP) in the presence of $6 \%(\mathrm{wt} / \mathrm{vol})$ polyvinyl alcohol (De Block \& Debrouwer 1993) resulting in a blue precipitate. The sections were counterstained with nuclear fast red. Thus, positive cells will have a blue cytoplasmatic staining, whereas negative cells will be pink. Finally, the sections were dehydrated through a series of ethanol and mounted with Euparal (Waldeck Gmbh \& Co Division Chroma, Münster, Germany). Sense probes were used to investigate the level of non-specific binding.

\section{Quantification and statistics}

First, a semi-quantitative screening of five different animals per group was performed to collect the in situ hybridization data. All tibiae were scored in a semi-quantitative manner 


\section{Osteoblast}
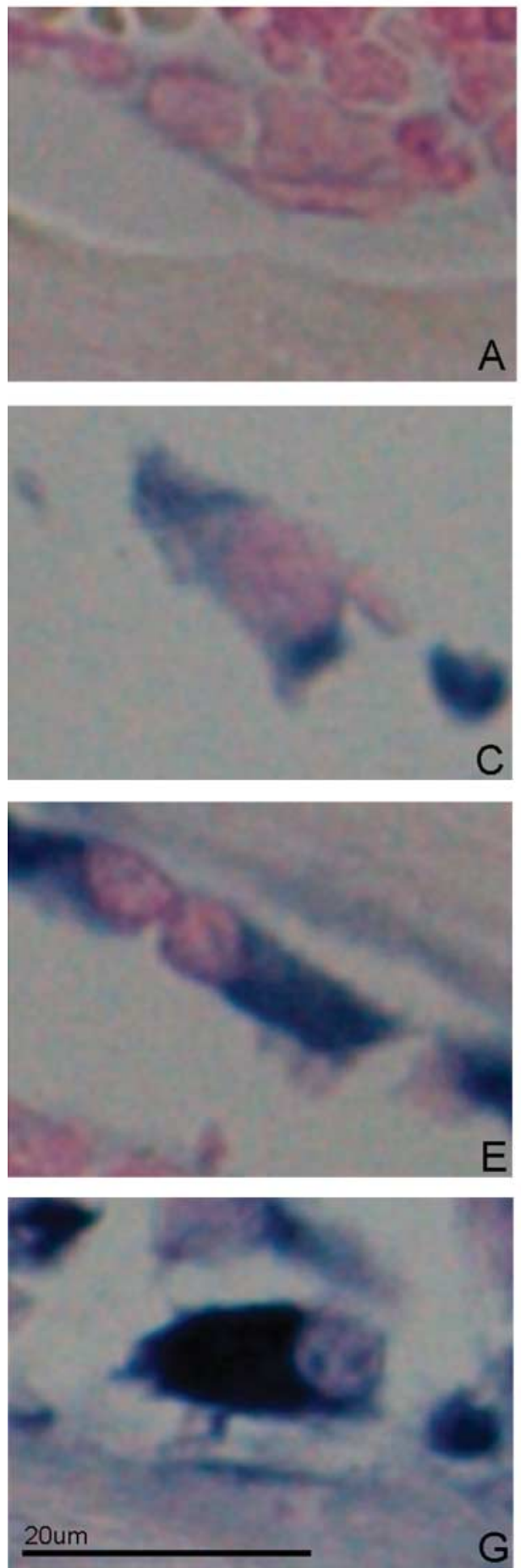

Osteocyte

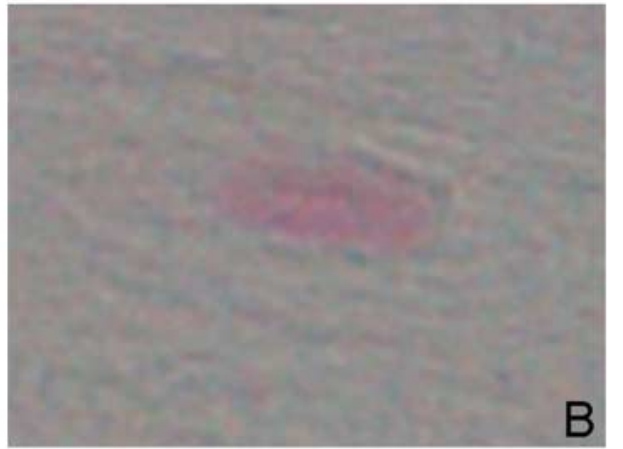

0

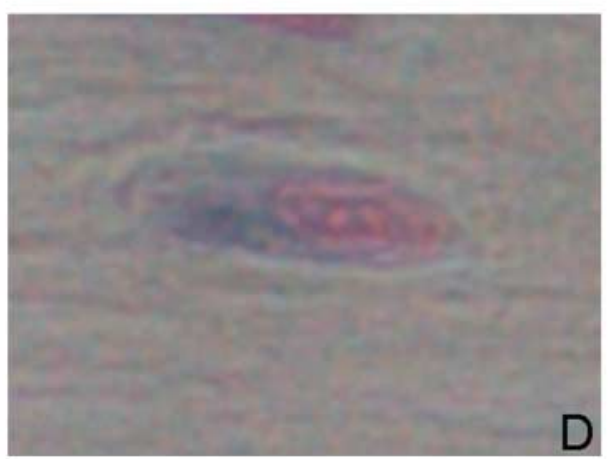

1

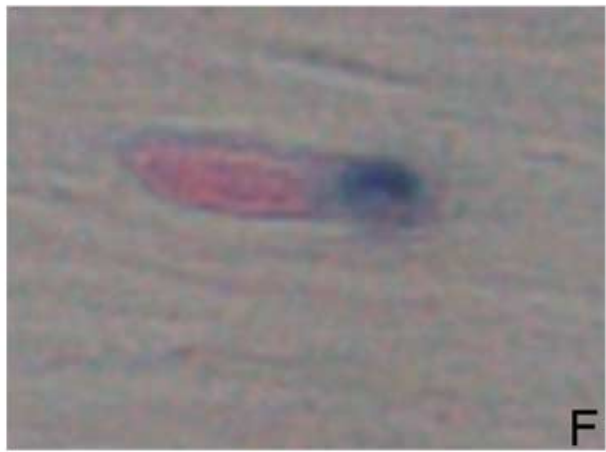

2

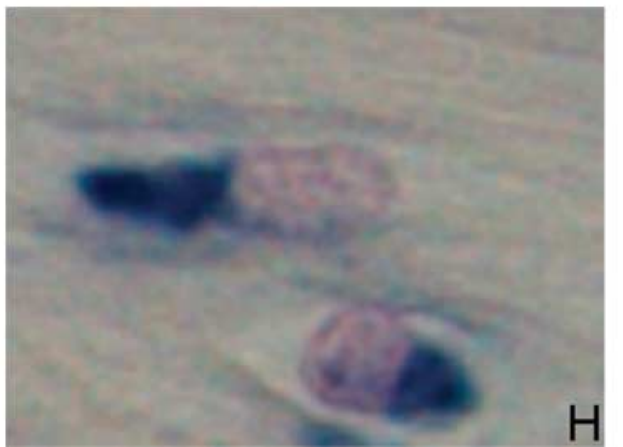

Figure 2 Representation of the semi-quantative scoring system assessing the levels of expression in the osteoblasts $(A, C, E$, and $G)$ and the osteocytes $(B, D, F$, and $H)$ in the tibiae of a 12-week-old female Wistar rat. Level 0 , no expression (A and B); level 1, low expression (C and D); level 2, average expression ( $E$ and $F$ ); and level 3, high expression $(\mathrm{G}$ and $\mathrm{H})$. The scale bar represents $20 \mu \mathrm{m}(\mathrm{A}-\mathrm{H})$. 
which was defined as follows: no expression (0), low expression (1), average expression, (2) and high expression (3) as shown in Fig. 2.

Effects of mechanical loading were expected in the shaft of the tibiae. Therefore, quantitative scoring of the endocortical osteocytes expressing IGF-I mRNA was performed with Lucia G Version 4.82 (Uvikon, Bunnik, The Netherlands) using coded slides of sections II and III. The defined area of interest, which comprised the loading zone, started below the primary spongiosa at the endosteal side of the shaft following the total length of the shaft to the distal side (total length maximal $3852 \mu \mathrm{m})$. At the endosteal side of the shaft all osteocytes, which were positioned within $100 \mu \mathrm{m}$ endosteal surface, were included in the area of interest. Within the area of interest, total osteocyte number and total IGF-I mRNA positive osteocyte number were measured using coded slides, resulting in a percentage of IGF-I mRNA positive osteocytes. We analyzed the sections of all rats per group within two different in situ hybridizations. The intraindividual mean S.D. of the quantitative measurement of the percentage positive osteocytes is $2.00 \%$ and the interindividual mean S.D. is $0 \cdot 94 \%$.

ANOVA (one-way ANOVA) was used for statistical analysis using SPSS version 9.0 for Windows. A $P$ value of $<0.05$ was considered to reflect statistical significance.

\section{Photography}

Brightfield photographs were made using Leica microscope (DM4000B) with a digital camera (Leica DC500) and the Leica software program IM50 (Leica Microsystems, Rijswijk, The Netherlands).

\section{IGF-I protein assay}

IGF-I protein was measured in serum by a RIA for the quantitative measurement of human somatomedin-C (BioSource, International, Camarillo, CA, USA). The intra-assay coefficient of variation was $<5 \cdot 2 \%(n=15)$ for levels between 925 and $2000 \mathrm{ng} / \mathrm{ml}$ and the inter-assay coefficient of variation was $<10 \%(n=20)$ for levels between 120 and $500 \mathrm{ng} / \mathrm{ml}$. The minimal detectable concentration was $35 \mathrm{ng} / \mathrm{ml}$.

\section{Results}

\section{Validation study four-point bending system}

The loaded right tibiae of the rats showed lamellar bone formation at the endosteal surface (Fig. 3A-C) and woven bone formation at the periosteal surface (Fig. 3A). The MS/BS expressed as a percentage of the bone surface of the loaded tibiae was $58 \%$, whereas the contralateral control tibiae showed a MS/BS of $40 \%$. The MS/BS of sham-loaded tibiae and its contralateral control tibiae was for both $38 \%$ (Table 1).
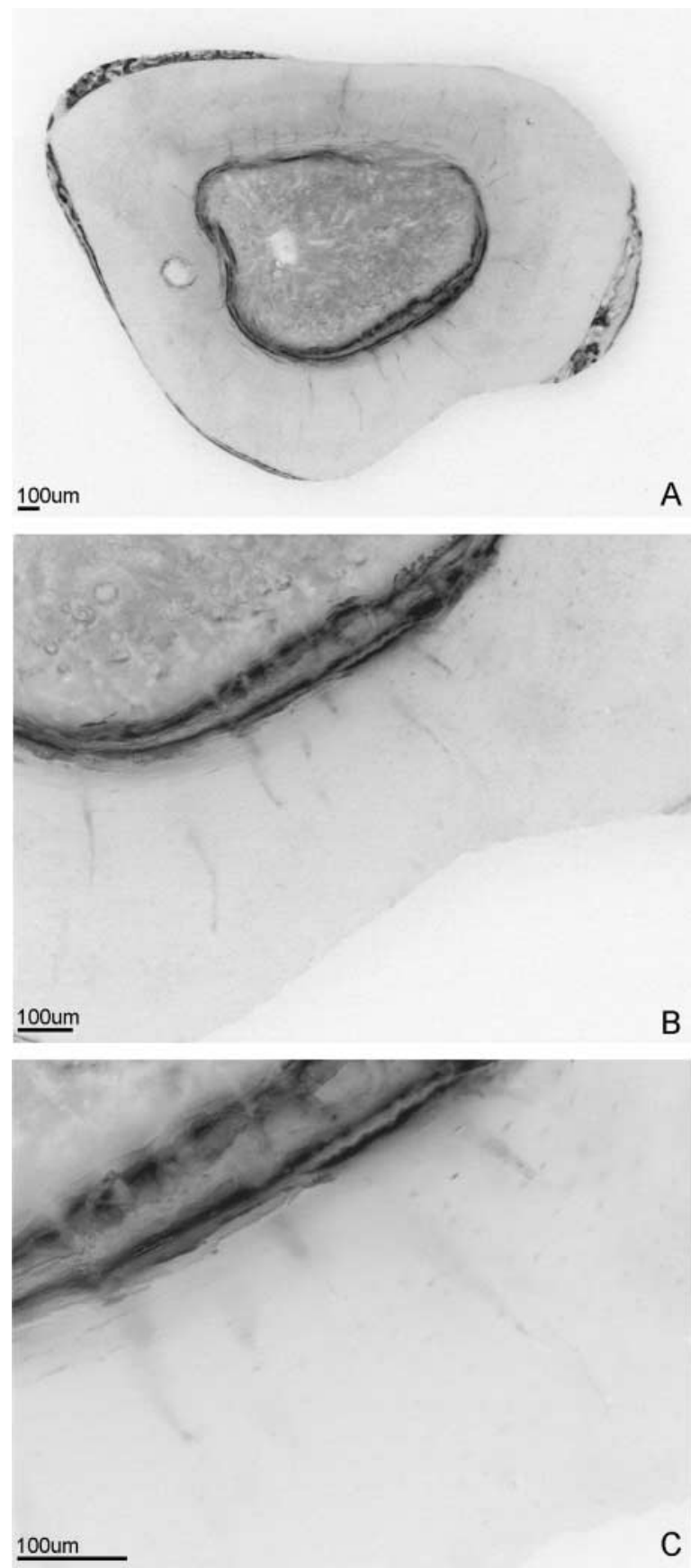

Figure 3 Photographs of fluorescence label in a cross-sectional sawing section of a loaded tibia. At the endosteal bone surface lamellar bone formation is shown (double label; A-C), whereas at the periosteal bone surface woven bone formation is present $(A)$.

\section{IGF-I protein concentrations in serum}

The IGF-I protein concentrations in serum, expressed as mean \pm s.E.M., were $1506 \pm 126 \mathrm{ng} / \mathrm{ml}$ in the control group, $1409 \pm 155 \mathrm{ng} / \mathrm{ml}$ in the load group, and $1408 \pm 93 \mathrm{ng} / \mathrm{ml}$ in 
Table 1 Mineralizing surface and mineral apposition rate of the endosteal bone surface. Data are mean values for each group of rats.

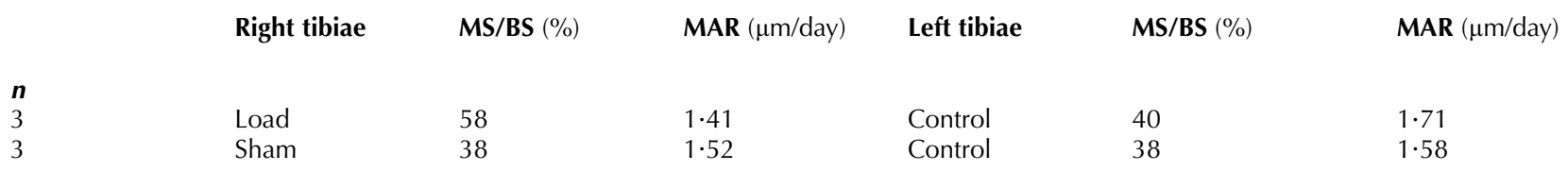

MS/BS, mineralizing surface is expressed as a percentage of the bone surface; MAR, mineral apposition rate. MAR is defined as the mean distance between the fluorescent labels divided by the labeling period.

the sham group respectively. Differences between groups were not observed $(P$ value $=0 \cdot 808)$.

\section{Ribosomal $28 \mathrm{~S}$ RA expression in tibiae}

Analysis of ribosomal 28S RNA in control tibiae using nonradioactive in situ hybridization exhibited cytoplasmatic expression within every cell type, including all osteocytes (Fig. 4A), osteoblasts (Fig. 4A), chondrocytes, and bone marrow cells (data not shown). Control hybridizations of control tibiae with the sense rRNA probe showed no signals (Fig. 4B).

\section{Endogenous IGF-I $m R N A$ expression in tissue}

The control brain showed IGF-I mRNA expression in Purkinje cells of the cerebellum and in neurons of the medulla oblongata (data not shown). In the internal control, i.e. the growth plate, IGF-I mRNA was located in chondrocytes of the proliferative and the hypertrophic zone (Fig. 4C). In control tibiae, IGF-I mRNA was expressed in osteoblasts, which were situated against the surface of trabecular bone (Fig. 4C) and endocortical bone (Fig. 4E). IGF-I mRNA expression was also observed in osteocytes, which were lying within the first lamella at the endosteal side of the shaft (Fig. 4E) and some trabecular osteocytes (Fig. 4C). The endocortical osteocytes, which were located within the deeper lamellae (Fig. 4E), and the periosteal osteocytes (data not shown) did not express IGF-I mRNA. IGF-I mRNA was expressed in the intracortical endothelial cells of blood vessels (Fig. 4F) and in the periosteum of control tibiae (data not shown). Some cells of the bone marrow i.e. megakaryocytes, macrophages, and myeloid cells also expressed IGF-I mRNA (data not shown).

Control hybridization of tibiae sections with the corresponding sense RNA probe did not show signals (Fig. 4D).

\section{Effect of mechanical loading on IGF-I $m R N A$ expression in osteocytes of the tibia shaft}

Mechanical loading induced IGF-I mRNA expression in osteocytes within multiple layers at the endosteal side of the shaft of the tibia in contrast to the contra-lateral control tibia, where IGF-I mRNA expression was only seen within the superficial layer at the endosteal side of the shaft (Fig. 4E and F). Quantitative analysis of the osteocytes within the endosteal side of the shaft showed a twofold increase of IGF-I mRNA expression $6 \mathrm{~h}$ after mechanical loading (Figs 4F and 5). The proportion of IGF-I mRNA-positive osteocytes was $29 \cdot 3 \pm 12 \cdot 9 \%$ (mean \pm S.D.) for loaded tibiae $(n=5), 16 \cdot 7 \pm 4 \cdot 4 \% \quad($ mean \pm s.D. $)$ for sham-loaded tibiae $(n=5)$, and $14 \cdot 7 \pm 4 \cdot 2 \%$ (mean \pm s.D.) for contra-lateral control tibiae $(n=10$; Fig. 5). Mechanical loading significantly increased the number of osteocytes, which express IGF-I mRNA $(P<0 \cdot 01$, load versus contra-lateral control and $P<0 \cdot 05$, load versus sham (Fig. 5)).

Effects of mechanical loading on IGF-I $m R N A$ expression in osteoblasts, chondrocytes, and bone marrow cells

No differences in IGF-I mRNA expression between loaded, sham-loaded, and contra-lateral control tibiae were observed in the osteoblasts, chondrocytes, and bone marrow cells by semi-quantitative screening. No differences in morphology of the cells were observed between groups.

\section{Discussion}

This in vivo study showed that a single mechanical loading session was sufficient to increase lamellar bone formation at the endosteal side of loaded tibiae shaft and to increase the IGF-I mRNA synthesis in the endocortical osteocytes of loaded tibiae $6 \mathrm{~h}$ after a single period of mechanical stimulation with the four-point bending system. The twofold increase of IGF-I mRNA expression was restricted to osteocytes at the endosteal side of the shaft and the inner lamellae. Loaded tibiae exhibited a higher number of IGF-I mRNA-positive osteocytes within multiple endosteal lamellae than non-loaded tibiae, whereas sham-loaded tibiae showed a similar pattern of IGF-I mRNA expression in subendocortical osteocytes as non-loaded contra-lateral control tibiae. We conclude that the increase of IGF-I mRNA expression in the osteocytes is a consequence of bending, because squeezing of the tibiae during sham-loading did not influence the IGF-I mRNA expression pattern. We suggest that the IGF-I mRNA in the endocortical osteocytes plays a role in lamellar bone formation.

These results confirm previous findings. Lean et al. (1995) showed an increase of IGF-I mRNA in cortical and trabecular osteocytes of the eighth caudal vertebra $6 \mathrm{~h}$ after 

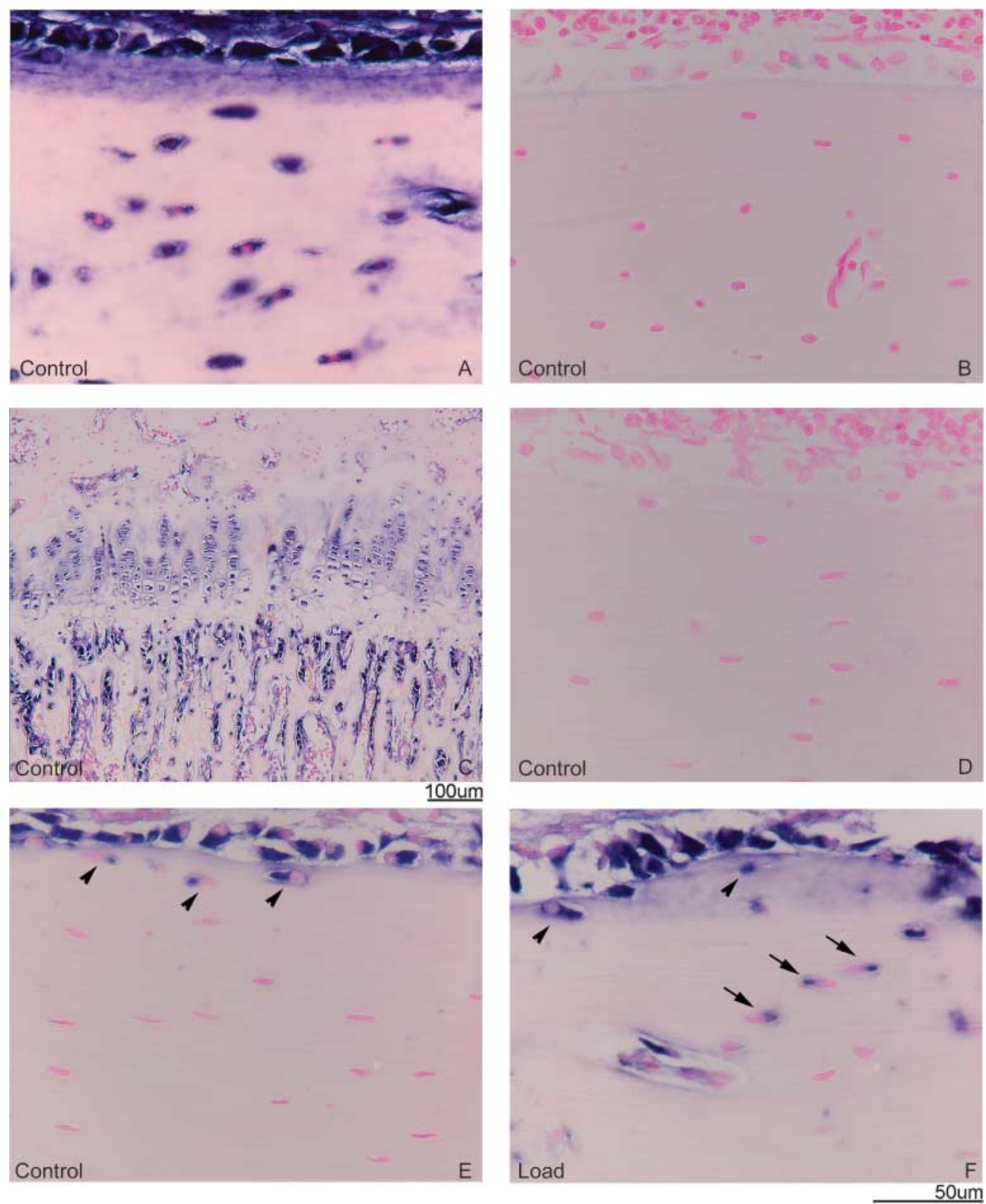

Figure 4 Expression of rRNA in (A) longitudinal control; tibiae sections and (C and E) IGF-I mRNA expression in longitudinal control; tibiae sections and (F) longitudinal loaded tibiae sections of 12-week-old female Wistar rats. The RNA signal is shown as a blue precipitate. The sections were counterstained with nuclear fast red and were visualized under brightfield illumination. The scale bars represent $50 \mu \mathrm{m}(\mathrm{A}$ and $\mathrm{B}, \mathrm{D}, \mathrm{E}$ and $\mathrm{F})$ and $100 \mu \mathrm{m}(\mathrm{C})$ respectively. (A) 28S rRNA expression within all endocortical osteocytes and osteoblasts; (B) hybridization with representative $28 \mathrm{~S}$ ribosomal sense probe showed no signal in the endocortical osteocytes and the osteoblasts; (C) IGF-I mRNA expression in the growth plate and primary spongiosa, the trabecular osteocytes, and the trabecular osteoblasts; (D) hybridization with a representative IGF-I sense probe showed no signal in the endocortical osteocytes and the osteoblasts; (E) IGF-I mRNA expression within the superficial endocortical osteocytes (indicated by arrow heads) and the osteoblasts of a contra-lateral control tibia; and (F) IGF-I mRNA expression in the endocortical osteocytes within multiple layers (indicated by arrow heads and by arrows) and the osteoblasts of a loaded tibia.

mechanical stimulation with the invasive vertebra compression model demonstrated by in situ hybridization and Raab-Cullen et al. (1994) showed an increase of IGF-I mRNA in the periosteum $4 \mathrm{~h}$ after loading with the four-point bending model demonstrated by northern blot (Raab-Cullen et al. 1994). Besides, IGF-I protein concentration in bone is also increased after stimulation by mechanical stress using additional weight-bearing 


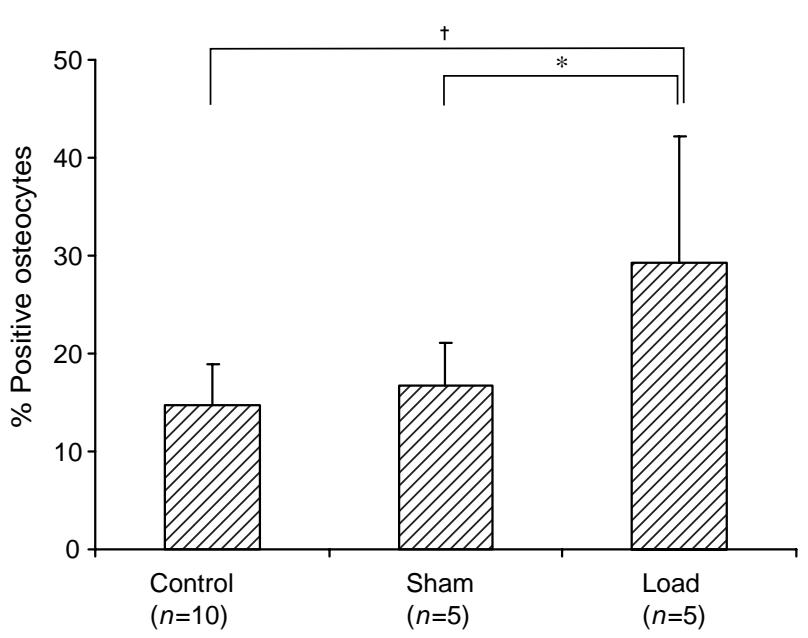

Figure 5 Influence of mechanical loading on IGF-I mRNA expression in the osteocytes at the endosteal side of the shaft of rat tibiae. Values are expressed as mean percentage positive osteocytes \pm s.D. $\left({ }^{\dagger} P<0 \cdot 01\right.$, load versus contra-lateral control; $* P<0 \cdot 05$, load versus sham).

(rat-with-backpack) as was previously reported (Bravenboer et al. 2001). The current study is the first study which showed a twofold increase of IGF-I mRNA in osteocytes in a non-invasive mechanical loading model (four-point bending model) at cellular level in vivo (non-radioactive in situ hybridization).

In addition, the twofold increase of IGF-I mRNA was specifically detected in the osteocytes at the endosteal side of the shaft within the deeper lamellae. It has generally been accepted that osteocytes are responsible for the predominant sensing of mechanical strains in bone (Klein-Nulend et al. 1995). It can be concluded that the osteocytes at the endosteal side of the shaft and the inner lamellae are mechanosensitive, since these osteocytes synthesize IGF-I mRNA $6 \mathrm{~h}$ after mechanical loading. This is also shown by Gross et al. (2002) who reported that mice overexpressing IGF-I in osteoblasts had an increased periosteal bone formation, suggesting that IGF-I increased sensitivity of the osteocytes and the osteoblasts.

Furthermore, we suggest that the mechanosensitive osteocytes, which synthesize IGF-I mRNA $6 \mathrm{~h}$ after mechanical loading, are important for the increased lamellar bone formation after mechanical loading. Forwood et al. (1996) reported that a single short period of loading, using the four-point bending model, resulted in an increased lamellar bone formation rate at the endosteal surface of rat tibia. Mechanical loading with an external bending load of $60 \mathrm{~N}$ in vivo will result in an increased woven bone formation rate at the periosteal surface and increased lamellar bone formation rate at the endosteal surface (Forwood et al. 1998). This has been confirmed in the validation study at our laboratory which showed that a single mechanical loading session was sufficient to induce lamellar bone formation at the endosteal side of the tibiae and the woven bone at the periosteal bone side. The lamellar bone formation is located at the endosteal side of the shaft, which is similar to the location of newly synthesized IGF-I mRNA after mechanical loading. This study also showed that IGF-I mRNA expression was not observed in the osteocytes at the periosteal side of the shaft, but was restricted to the sub-endocortical osteocytes and the osteocytes in multiple lamellae. The IGF-I mRNA may be less involved by the woven bone formation, which is the result of irritation of the periosteum (Forwood et al. 1998). This suggests that IGF-I mRNA in the mechanosensitive osteocytes is specifically important for lamellar bone formation.

No differences in serum IGF-I concentrations were observed between loaded, sham-loaded, and control groups. This implies that the acute effect of mechanical loading is restricted to the bone region, which is deformed, because the systemic serum IGF-I concentrations are unaffected. This supports the hypothesis that the osteogenic response to mechanical loading occurs locally (Bravenboer et al. 2001). However, the level of IGF-I mRNA, which has to be produced at a single skeletal site to observe the effect on IGF-I protein in the serum, is unknown. A twofold up-regulation of IGF-I mRNA in one tibia might be too low.

The other bone cells in the tibiae and the bone marrow cells showed no difference in IGF-I mRNA expression before and $6 \mathrm{~h}$ after mechanical loading. Our results showed that osteoblasts and osteocytes, within the first lamella at the endosteal side of the shaft and the trabecular bone, synthesize IGF-I mRNA. These bone cells play a role during bone remodeling. Although the osteoblasts are responsible for new bone formation after loading, their IGF-I mRNA expression was not increased after mechanical stimulation; this is probably due to the fact that the endogenous IGF-I mRNA expression level in osteoblasts was very high. Several investigators have also demonstrated endogenous IGF-I mRNA expression within the osteocytes of rodents (Inaoka et al. 1995, Mason et al. 1996, Zhao et al. 2000). In contrast, a number of other studies did not observe endogenous IGF-I mRNA expression within the osteocytes of rodents and humans (Yeh et al. 1993, Lean et al. 1995, Middleton et al. 1995). These contradictory results could be explained by the fact that different bones, including tibiae, distal femurs, ulnae, and vertebrae, were examined. The daily loading of these bones varies considerably, which results in differences in gene expression. A second explanation could be the use of various molecular techniques and the preparation of the bone tissue, either undecalcified bone or decalcified bone. Finally, there is a difference in age between the studied species.

For this study, we used the four-point bending model of Forwood, because this four-point bending apparatus produces a controlled mechanical strain in the tibia of living rats. An advantage of this approach is that it does not require surgical intervention and allows normal physical activity after the loading session (Turner et al. 1991, Forwood et al. 1998). The osteogenic response will occur locally in bone. Therefore, we have used the in situ hybridization technique in order to detect the local osteogenic response at the cellular level. The nonradioactive in situ hybridization method is a powerful and 
sensitive technique method to localize gene expression within decalcified rat tibiae. In this study, a ribosomal 28S RNA probe was used to verify the RNA integrity of the decalcified tibiae. All bone cells, including osteocytes and osteoblasts, and chondrocytes and bone marrow cells showed ribosomal $28 \mathrm{~S}$ RNA expression within the cytoplasm. Therefore, we conclude that the RNA integrity was maintained during the entire decalcification and embedding procedure. It is demonstrated that the IGF-I cRNA probe is specific, because the brain showed IGF-I mRNA expression in the Purkinje cells of the cerebellum and in neurons of the medulla oblongata as described earlier (Bondy et al. 1992, D'Ercole et al. 1996, Reijnders et al. 2004) and IGF-I mRNA was expressed in the chondrocytes of the proliferative and the hypertrophic zone of the growth plate as shown earlier by Reinecke and Nilsson (Nilsson et al. 1990, Reinecke et al. 2000).

Nevertheless, this study has some limitations. The applied load of $60 \mathrm{~N}$ is supra-physiological and the insulin-like growth factor-binding proteins (IGFBPs) have not been studied. IGF-I is one component of the IGF system. IGFBPs can influence the biological activity of IGF-I (Firth \& Baxter 2002) by regulating the bioavailability of IGFs (Collett-Solberg \& Cohen 1996). Therefore, it is necessary to study the effects of mechanical loading on local IGFBP expression level as well.

In conclusion, this study shows that IGF-I mRNA is twofold up-regulated within the endocortical osteocytes of the shaft and multiple layers extending into the cortical bone $6 \mathrm{~h}$ after mechanical loading in vivo. We conclude that these osteocytes are mechanosensitive as shown by newly synthesized IGF-I mRNA after a single short period of loading. This supports the hypothesis that these osteocytes translate mechanical stimuli into bone formation through IGF-I. The process occurs rather early in a series of cellular events, which take place after mechanical loading.

\section{Acknowledgements}

The authors thank Marie Lomecky, Jeany Huijser, and Glenn Hek (Endocrine Laboratory) for measuring the IGF-I serum protein concentrations, and Huib van Essen (Department of Endocrinology), and Esther Lok, Suzanne Bonne and Paula Mul (Clinical Laboratory for Animal Experiments) for assisting with the animal experiments, and finally Paulien Holzmann (Department of Endocrinology) for technical assistance. The authors declare that there is no conflict of interest that would prejudice the impartiality of this scientific work.

\section{References}

Bondy C, Werner H, Roberts CT Jr \& LeRoith D 1992 Cellular pattern of type-I insulin-like growth factor receptor gene expression during maturation of the rat brain: comparison with insulin-like growth factors I and II. Neuroscience 46 909-923.
Bravenboer N, Engelbregt MJ, Visser NA, Popp-Snijders C \& Lips P 2001 The effect of exercise on systemic and bone concentrations of growth factors in rats. Journal of Orthopaedic Research 19 945-949.

Collett-Solberg PF \& Cohen P 1996 The role of the insulin-like growth factor binding proteins and the IGFBP proteases in modulating IGF action. Endocrinology and Metabolism Clinics of North America 25 591-614.

Cowin SC, Moss-Salentijn L \& Moss ML 1991 Candidates for the mechanosensory system in bone. Journal of Biomechanical Engineering 113 191-197.

Davidovitch Z, Shanfeld JL, Montgomery PC, Lally E, Laster L, Furst L \& Korostoff E 1984 Biochemical mediators of the effects of mechanical forces and electric currents on mineralized tissues. Calcified Tissue International $\mathbf{3 6}$ (Suppl 1) S1-S97.

De Block M \& Debrouwer D 1993 RNA-RNA in situ hybridization using digoxigenin-labeled probes: the use of high-molecular-weight polyvinyl alcohol in the alkaline phosphatase indoxyl-nitroblue tetrazolium reaction. Analytical Biochemistry 215 86-89.

D'Ercole AJ, Ye P, Calikoglu AS \& Gutierrez-Ospina G 1996 The role of the insulin-like growth factors in the central nervous system. Molecular Neurobiology 13 227-255.

Firth SM \& Baxter RC 2002 Cellular actions of the insulin-like growth factor binding proteins. Endocrine Reviews 23 824-854.

Forwood MR 1996 Inducible cyclo-oxygenase (COX-2) mediates the induction of bone formation by mechanical loading in vivo. Journal of Bone and Mineral Research 11 1688-1693.

Forwood MR \& Parker AW 1991 Repetitive loading, in vivo, of the tibiae and femora of rats: effects of repeated bouts of treadmill-running. Bone and Mineral 13 35-46.

Forwood MR, Owan I, Takano Y \& Turner CH 1996 Increased bone formation in rat tibiae after a single short period of dynamic loading in vivo. American Journal of Physiology 270 E419-E423.

Forwood MR, Bennett MB, Blowers AR \& Nadorfi RL 1998 Modification of the in vivo four-point loading model for studying mechanically induced bone adaptation. Bone 23 307-310.

Gross TS, Srinivasan S, Liu CC, Clemens TL \& Bain SD 2002 Noninvasive loading of the murine tibia: an in vivo model for the study of mechanotransduction. Journal of Bone and Mineral Research 17 493-501.

Hamdy RC, Anderson JS, Whalen KE \& Harvill LM 1994 Regional differences in bone density of young men involved in different exercises. Medicine and Science in Sports and Exercise 26 884-888.

Inaoka T, Lean JM, Bessho T, Chow JW, Mackay A, Kokubo T \& Chambers TJ 1995 Sequential analysis of gene expression after an osteogenic stimulus: c-fos expression is induced in osteocytes. Biochemical and Biophysical Research Communications 217 264-270.

Jansen M, van Schaik FM, Ricker AT, Bullock B, Woods DE, Gabbay KH, Nussbaum AL, Sussenbach JS \& Van den Brande JL 1983 Sequence of cDNA encoding human insulin-like growth factor I precursor. Nature 306 609-611.

Klein-Nulend J, van der Plas A, Semeins CM, Ajubi NE, Frangos JA, Nijweide PJ \& Burger EH 1995 Sensitivity of osteocytes to biomechanical stress in vitro. FASEB Journal: Official Publication of the Federation of American Societies for Experimental Biology 9 441-445.

Lanyon LE 1992 Control of bone architecture by functional load bearing. Journal of Bone and Mineral Research 7(Suppl 2) S369-S375.

Lean JM, Jagger CJ, Chambers TJ \& Chow JW 1995 Increased insulin-like growth factor I mRNA expression in rat osteocytes in response to mechanical stimulation. American Journal of Physiology 268 E318-E327.

Lean JM, Mackay AG, Chow JW \& Chambers TJ 1996 Osteocytic expression of mRNA for c-fos and IGF-I: an immediate early gene response to an osteogenic stimulus. American Journal of Physiology 270 E937-E945.

Mason DJ, Hillam RA \& Skerry TM 1996 Constitutive in vivo mRNA expression by osteocytes of beta-actin, osteocalcin, connexin-43, IGF-I, c-fos and c-jun, but not TNF-alpha nor tartrate-resistant acid phosphatase. Journal of Bone and Mineral Research 11 350-357.

Mason DJ, Suva LJ, Genever PG, Patton AJ, Steuckle S, Hillam RA \& Skerry TM 1997 Mechanically regulated expression of a neural glutamate transporter in bone: a role for excitatory amino acids as osteotropic agents? Bone 20 199-205. 
Melton DA, Krieg PA, Rebagliati MR, Maniatis T, Zinn K \& Green MR 1984 Efficient in vitro synthesis of biologically active RNA and RNA hybridization probes from plasmids containing a bacteriophage SP6 promoter. Nucleic Acids Research 12 7035-7056.

Middleton J, Arnott N, Walsh S \& Beresford J 1995 Osteoblasts and osteoclasts in adult human osteophyte tissue express the mRNAs for insulin-like growth factors I and II and the type 1 IGF receptor. Bone 16 287-293.

Nilsson A, Carlsson B, Isgaard J, Isaksson OG \& Rymo L 1990 Regulation by GH of insulin-like growth factor-I mRNA expression in rat epiphyseal growth plate as studied with in situ hybridization. Journal of Endocrinology 125 67-74.

Nomura S \& Takano-Yamamoto T 2000 Molecular events caused by mechanical stress in bone. Matrix Biology 19 91-96.

Pitsillides AA, Rawlinson SC, Suswillo RF, Bourrin S, Zaman G \& Lanyon LE 1995 Mechanical strain-induced NO production by bone cells: a possible role in adaptive bone (re)modeling? FASEB Journal: Official Publication of the Federation of American Societies for Experimental Biology 9 1614-1622.

Raab-Cullen DM, Thiede MA, Petersen DN, Kimmel DB \& Recker RR 1994 Mechanical loading stimulates rapid changes in periosteal gene expression. Calcified Tissue International 55 473-478.

Reijnders CM, Koster JG \& Buul-Offers SC 2004 Overexpression of human IGF-II mRNA in the brain of transgenic mice modulates IGFBP2 gene expression in the medulla oblongata. Journal of Endocrinology 182 445-455.

Reinecke M, Schmid AC, Heyberger-Meyer B, Hunziker EB \& Zapf J 2000 Effect of growth hormone and insulin-like growth factor I (IGF-I) on the expression of IGF-I messenger ribonucleic acid and peptide in rat tibial growth plate and articular chondrocytes in vivo. Endocrinology 141 2847-2853

Skerry TM 1999 Identification of novel signaling pathways during functional adaptation of the skeleton to mechanical loading: the role of glutamate as a paracrine signaling agent in the skeleton. Journal of Bone and Mineral Metabolism 17 66-70

Skerry TM \& Genever PG 2001 Glutamate signalling in non-neuronal tissues. Trends in Pharmacological Sciences 22 174-181.

Skerry TM \& Suva LJ 2003 Investigation of the regulation of bone mass by mechanical loading: from quantitative cytochemistry to gene array. Cell Biochemistry and Function 21 223-229.

Skerry TM, Bitensky L, Chayen J \& Lanyon LE 1989 Early strain-related changes in enzyme activity in osteocytes following bone loading in vivo. Journal of Bone and Mineral Research 4 783-788.
Smink JJ, Koster JG, Gresnigt MG, Rooman R, Koedam JA \& Buul-Offers SC 2002 IGF and IGF-binding protein expression in the growth plate of normal, dexamethasone-treated and human IGF-II transgenic mice. Journal of Endocrinology 175 143-153.

Smith R \& Rutherford OM 1993 Spine and total body bone mineral density and serum testosterone levels in male athletes. European Journal of Applied Physiology and Occupational Physiology 67 330-334.

Torrance AG, Mosley JR, Suswillo RF \& Lanyon LE 1994 Noninvasive loading of the rat ulna in vivo induces a strain-related modeling response uncomplicated by trauma or periostal pressure. Calcified Tissue International 54 241-247.

Turner CH, Akhter MP, Raab DM, Kimmel DB \& Recker RR 1991 A noninvasive, in vivo model for studying strain adaptive bone modeling. Bone $1273-79$.

Turner CH, Forwood MR, Rho JY \& Yoshikawa T 1994 Mechanical loading thresholds for lamellar and woven bone formation. Journal of Bone and Mineral Research 9 87-97.

van der Wiel HE, Lips P, Graafmans WC, Danielsen CC, Nauta J, van Lingen A \& Mosekilde L 1995 Additional weight-bearing during exercise is more important than duration of exercise for anabolic stimulus of bone: a study of running exercise in female rats. Bone 16 73-80.

Wilkinson DG 1992 In situ Hybridization: A Practical Approach. Oxford University Press., Oxford: Oxford University.

Yeh JK, Liu CC \& Aloia JF 1993 Effects of exercise and immobilization on bone formation and resorption in young rats. American Journal of Physiology 264 E182-E189.

Zhao G, Monier-Faugere MC, Langub MC, Geng Z, Nakayama T, Pike JW, Chernausek SD, Rosen CJ, Donahue LR, Malluche HH et al. 2000 Targeted overexpression of insulin-like growth factor I to osteoblasts of transgenic mice: increased trabecular bone volume without increased osteoblast proliferation. Endocrinology $1412674-2682$.

\section{Received in final form 10 September 2006 \\ Accepted 19 September 2006 \\ Made available online as an Accepted Preprint 27 October 2006}

